Eds P. Gopalakrishnakone, Vidal Haddad Jr., William

R. Kem, Aurelia Tubaro, Euikyung Kim, Springer

ISBN 9789400766501

http://dx.doi.org/10.1007/978-94-007-6650-1 20-1

http://archimer.ifremer.fr/doc/00320/43146/

๑) Springer International Publishing Switzerland 2015

\title{
Azaspiracid Toxins: Toxicological Profile
}

\author{
Philipp Hess ${ }^{1,{ }^{*}}$, Michael J. Twiner ${ }^{2}$, Jane Kilcoyne ${ }^{3}$, Silvio Sosa ${ }^{4}$
}

\author{
${ }^{1}$ Ifremer, Laboratoire Phycotoxines, Rue de l'lle d'Yeu, 44311, Nantes, France \\ ${ }^{2}$ School of Medicine, Wayne State University, Detroit, MI, USA \\ ${ }^{3}$ Marine Institute, Renville, Oranmore, County Galway, Ireland \\ ${ }^{4}$ Department of Life Sciences, University of Trieste, Trieste, Italy \\ *: Corresponding author : Philipp Hess, email address : philipp.hess@ifremer.fr \\ mtwiner@med.wayne.edu ; Jane.Kilcoyne@marine.ie ; silvio.sosa@econ.units.it
}

\begin{abstract}
:
Azaspiracids (AZAs) are a toxin group that originate from marine dinoflagellates of the genera Azadinium and Amphidoma. After accumulation of these toxins in edible marine organisms and their subsequent consumption, humans develop a gastrointestinal syndrome referred to as azaspiracid shellfish poisoning (AZP). This syndrome is very similar to diarrheic shellfish poisoning (DSP), with main symptoms appearing after a few hours from consumption and including diarrhea, vomiting, and stomach cramps. Due to extensive metabolism in shellfish, more than 30 analogues have been reported to date, and purified compounds for selected analogues have recently been made available for toxicological studies. Currently, only AZA1, AZA2, and AZA3 are regulated in Europe and internationally; however, more recent evidence suggests that AZA6, AZA17, and AZA19 may also be analogues of importance for estimating the full risk of seafood.
\end{abstract}

Even though animal studies have pointed out target organs (digestive tract, liver, heart, and lung), mechanism of action studies at cellular level are not yet conclusive. While a number of common targets have been excluded (protein phosphatases, kinases, actin depolymerization, G proteincoupled receptors), some evidence points toward ion channel activity of AZAs. Still, in vitro studies do not correlate well with symptoms observed in humans. Also, while some animal studies point toward longer-term effects, no such evidence has been reported from human poisoning events. However, it should be noted that in-depth epidemiological studies are still lacking. Even though all risk assessments have based their evaluation on a single, relatively early poisoning event in 1997, in Arranmore Island, Ireland, producing organisms and toxin occurrences have been reported worldwide, and further occurrence studies should provide a better base for such epidemiological studies.

Keywords : Azaspiracids ; Azaspiracid shellfish poisoning ; Harmful algae ; Azadinium ; Shellfish 


\section{Introduction}

Azaspiracids (AZAs) are marine algal toxins produced by the dinoflagellate genera Azadinium (Krock et al. 2009; Tillmann et al. 2009) and Amphidoma (Tillmann et al. 2012, 2014). This class of toxins was first identified in the 1990s following an outbreak of human illness in the Netherlands associated with consumption of contaminated mussels from Killary Harbour, Ireland (McMahon and Silke 1996). Although the symptoms were typical of DSP toxins, i.e., okadaic acid (OA) and dinophysistoxins (DTXs), the levels of DSP toxins in these mussels were well below the regulatory level. Subsequently, it was established that the shellfish were contaminated with a unique marine

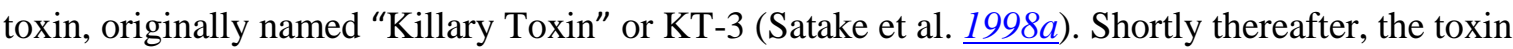
was renamed to azaspiracid (AZA) to more appropriately reflect its chemical structure: a cyclic amine, or aza group, with a tri-spiro-assembly and carboxylic acid group (Satake et al. $\underline{1998 a}, \underline{b}$ ). To date, over 30 AZA analogues have been identified in phytoplankton and shellfish (Hess et al. 2014; James et al. 2003b; Jauffrais et al. 2012b; Lehane et al. 2002; McCarron et al. 2009; Ofuji et al. 1999, 2001; Rehmann et al. 2008; Satake et al. 1998b). Over the last 15 years, AZAs have been reported in shellfish from many coastal regions of Western Europe (Amzil et al. 2008; Magdalena et al. 2003a; Furey et al. 2003; Hess et al. 2007; James et al. 2001, 2002; Twiner et al. 2008), Northern Africa (Elgarch et al. 2008; Taleb et al. 2006), South America (Álvarez et al. 2010), and North America (M. Quilliam, pers. comm.; A. Robertson, pers. comm.). In addition, AZAs have been found in Japanese sponges (Ueoka et al. 2009) and Scandinavian crabs (Torgersen et al. 2008). Not surprisingly, the global distribution of AZAs appears to correspond to the apparent widespread occurrence of Azadinium (Akselman and Negri 2012; Tillmann et al. 2010, 2011). Empirical evidence is now available that unambiguously demonstrates the accumulation of AZAs in shellfish via direct feeding on AZA-producing A. spinosum (Jauffrais et al. 2012c; Salas et al. 2011).

Whereas extensive study of this toxin class has been historically constrained by limited availability of purified material, these restraints are now less of an impediment due to advances in isolation and purification of AZAs from naturally contaminated shellfish (Kilcoyne et al. 2012) and the identification of the toxigenic organism A. spinosum coupled with its mass culture in bioreactors (Jauffrais et al. 2012b). As such, certified reference standards of naturally produced AZA1-3 are now commercially available (Perez et al. 2010). Although not yet realized for commercial purposes, limits on toxin supply may be further alleviated by advances in the organic total synthesis of AZA1

(Nicolaou et al. 2004) and AZA3 (C. Forsyth, pers. comm.). Accessibility to purified AZAs has led to rapid progress with respect to understanding AZA toxicology over the last few years.

\section{Toxins}

\section{Biosynthesized (Algal) Analogues}

AZAs have sporadically been detected in plankton (James et al. 2003a; Krock et al. 2008) and seawater (Fux et al. 2009; Rundberget et al. 2007), but no progenitor of these toxins could be assigned until 2007 (Krock et al. 2009), when a small dinoflagellate, later named Azadinium spinosum (Tillmann et al. 2009), was unambiguously identified as an AZA1- and AZA2-producing organism ( ca. 20 and $7 \mathrm{fg} /$ cell, respectively). Later, Kilcoyne et al. found additional AZAs with molecular masses of 715 ( $c a .7 \mathrm{fg} / \mathrm{cell}$ ) and $816 \mathrm{Da}$ (AZA33 and AZA34) in environmental samples and cultures of A. spinosum (Kilcoyne et al. 2014b; Table 1).Table 1 
Structural variants of AZAs, their protonated masses, origin and toxicity

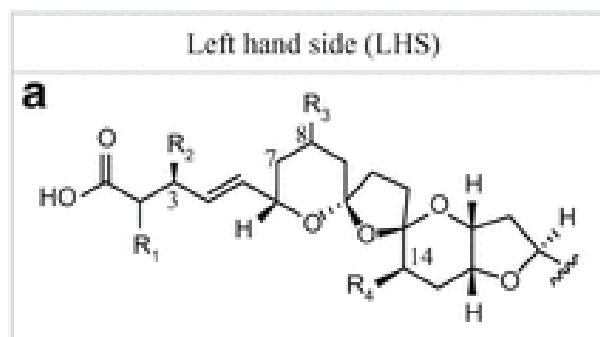

b

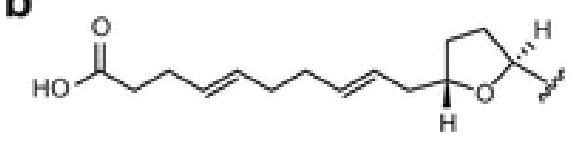

C
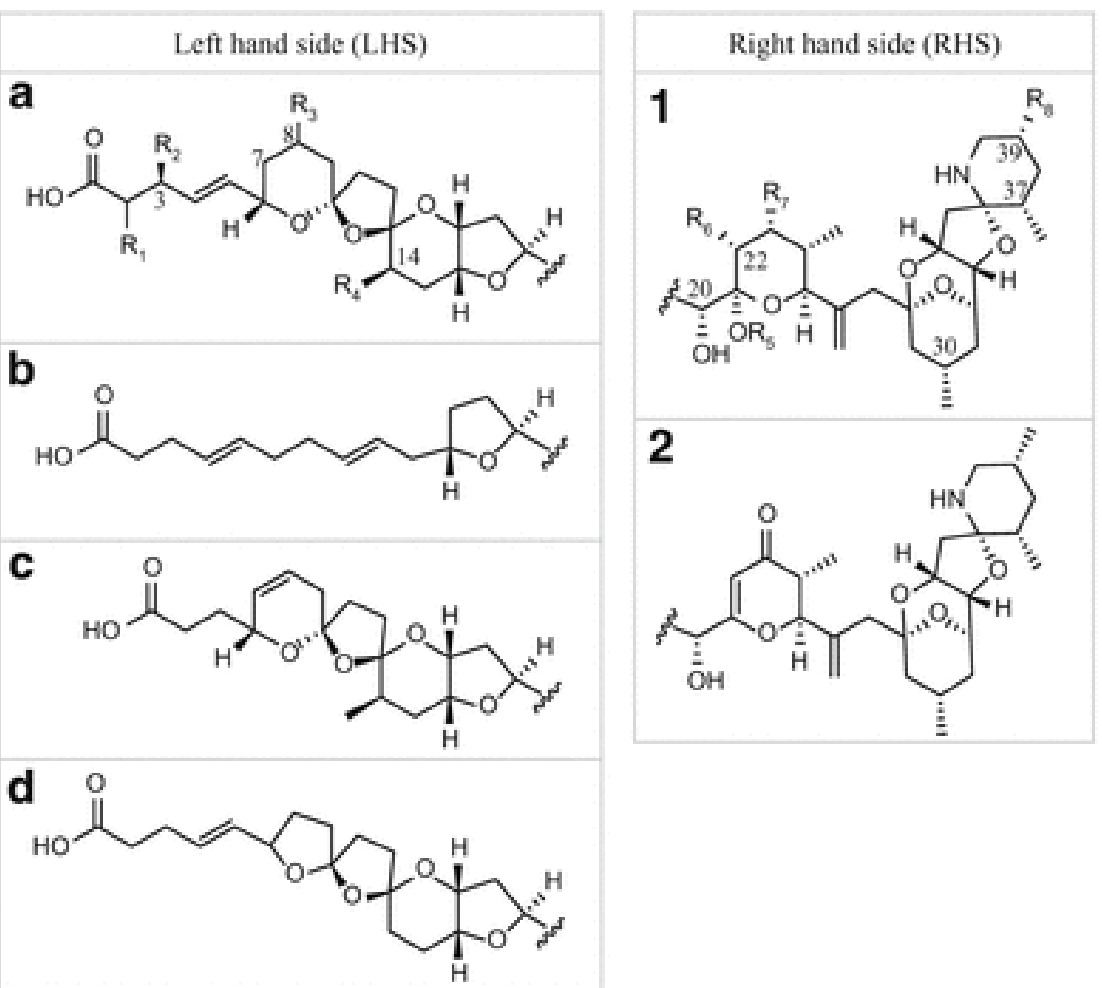

\begin{tabular}{|c|c|c|c|c|c|c|c|c|c|c|c|c|c|}
\hline & Type $^{6}$ & $\mathrm{R}_{1}$ & 7,8 & $\mathbf{R}_{2}$ & $\mathrm{R}_{3}$ & $\mathbf{R}_{4}$ & $R_{5}$ & $\mathrm{R}_{6}$ & $R_{7}$ & $\mathrm{R}_{\mathrm{g}}$ & {$[\mathrm{M}+\mathrm{H}]^{+}$} & Origin & Status \\
\hline AZA1 & a1 & H & $\Delta$ & $\mathrm{H}$ & $\mathrm{H}$ & $\mathrm{CH}_{3}$ & $\mathrm{H}$ & $\mathrm{CH}_{3}$ & $\mathrm{H}$ & $\mathrm{CH}_{3}$ & 842.5 & A. spinosum & phycotoxin \\
\hline "37-epi-AZA1 & a1 & H & $\Delta$ & $\mathrm{H}$ & $\mathrm{H}$ & $\mathrm{CH}_{3}$ & $\mathrm{H}$ & $\mathrm{CH}_{3}$ & $\mathrm{H}$ & $\mathrm{CH}_{3}$ & 842.5 & A. spinosum & artefact \\
\hline AZAZ & a1 & H & $\Delta$ & $\mathrm{H}$ & $\mathrm{CH}_{3}$ & $\mathrm{CH}_{3}$ & H & $\mathrm{CH}_{3}$ & H & $\mathrm{CH}_{3}$ & 856.5 & A. spinosum & phycotoxin \\
\hline AZA3 & a1 & H & $\Delta$ & $\mathrm{H}$ & $\mathrm{H}$ & $\mathrm{CH}_{3}$ & H & H & H & $\mathrm{CH}_{3}$ & 828.5 & shellfish & metabolite \\
\hline AZA4 & a1 & H & $\Delta$ & $\mathrm{OH}$ & H & $\mathrm{CH}_{3}$ & H & H & H & $\mathrm{CH}_{3}$ & 844.5 & shellfish & metabolite \\
\hline AZAS & a1 & H & $\Delta$ & $\mathrm{H}$ & $\mathrm{H}$ & $\mathrm{CH}_{3}$ & H & H & $\mathrm{OH}$ & $\mathrm{CH}_{3}$ & 844.5 & shellfish & metabolite \\
\hline AZA6 & a1 & H & $\Delta$ & $\mathrm{H}$ & $\mathrm{CH}_{3}$ & $\mathrm{CH}_{3}$ & H & $\mathrm{H}$ & $\mathrm{H}$ & $\mathrm{CH}_{3}$ & 842.5 & shellfish & metabolite \\
\hline AZA7 & a1 & H & $\Delta$ & $\mathrm{OH}$ & $\mathrm{H}$ & $\mathrm{CH}_{3}$ & H & $\mathrm{CH}_{3}$ & $\mathrm{H}$ & $\mathrm{CH}_{3}$ & 858.5 & shellfish & metabolite \\
\hline AZA8 & a1 & H & $\Delta$ & $\mathrm{H}$ & $\mathrm{H}$ & $\mathrm{CH}_{3}$ & $\mathrm{H}$ & $\mathrm{CH}_{3}$ & $\mathrm{OH}$ & $\mathrm{CH}_{3}$ & 858.5 & shellfish & metabolite \\
\hline AZA9 & a1 & H & $\Delta$ & $\mathrm{OH}$ & $\mathrm{CH}_{3}$ & $\mathrm{CH}_{3}$ & $\mathrm{H}$ & $\mathrm{H}$ & $\mathrm{H}$ & $\mathrm{CH}_{3}$ & 858.5 & shellfish & metabolite \\
\hline AZA10 & a1 & H & $\Delta$ & $\mathrm{H}$ & $\mathrm{CH}_{3}$ & $\mathrm{CH}_{3}$ & H & $\mathrm{H}$ & $\mathrm{OH}$ & $\mathrm{CH}_{3}$ & 858.5 & shellfish & metabolite \\
\hline AZA11 & a1 & H & $\Delta$ & $\mathrm{OH}$ & $\mathrm{CH}_{3}$ & $\mathrm{CH}_{3}$ & $\mathrm{H}$ & $\mathrm{CH}_{3}$ & $\mathrm{H}$ & $\mathrm{CH}_{3}$ & 872.5 & shellfish & metabolite \\
\hline AZA12 & a1 & H & $\Delta$ & $\mathrm{H}$ & $\mathrm{CH}_{3}$ & $\mathrm{CH}_{3}$ & $\mathrm{H}$ & $\mathrm{CH}_{3}$ & $\mathrm{OH}$ & $\mathrm{CH}_{3}$ & 872.5 & shellfish & metabolite \\
\hline AZA13 & a1 & H & $\Delta$ & $\mathrm{OH}$ & $\mathrm{H}$ & $\mathrm{CH}_{3}$ & $\mathrm{H}$ & $\mathrm{H}$ & $\mathrm{OH}$ & $\mathrm{CH}_{3}$ & 860.5 & shellfish & metabolite \\
\hline AZA14 & a1 & H & $\Delta$ & $\mathrm{OH}$ & $\mathrm{H}$ & $\mathrm{CH}_{3}$ & H & $\mathrm{CH}_{3}$ & $\mathrm{OH}$ & $\mathrm{CH}_{3}$ & 874.5 & shellfish & metabolite \\
\hline AZA15 & a1 & H & $\Delta$ & $\mathrm{OH}$ & $\mathrm{CH}_{3}$ & $\mathrm{CH}_{3}$ & $\mathrm{H}$ & $\mathrm{H}$ & $\mathrm{OH}$ & $\mathrm{CH}_{3}$ & 874.5 & shellfish & metabolite \\
\hline AZA16 & a1 & H & $\Delta$ & $\mathrm{OH}$ & $\mathrm{CH}_{3}$ & $\mathrm{CH}_{3}$ & $\mathrm{H}$ & $\mathrm{CH}_{3}$ & $\mathrm{OH}$ & $\mathrm{CH}_{3}$ & 888.5 & shellfish & metabolite \\
\hline AZA17 & a1 & H & $\Delta$ & $\mathrm{H}$ & $\mathrm{H}$ & $\mathrm{CH}_{3}$ & $\mathrm{H}$ & $\mathrm{COOH}$ & $\mathrm{H}$ & $\mathrm{CH}_{3}$ & 872.5 & shellfish & metabolite \\
\hline AZA19 & a1 & H & $\Delta$ & $\mathrm{H}$ & $\mathrm{CH}_{3}$ & $\mathrm{CH}_{3}$ & $\mathrm{H}$ & $\mathrm{COOH}$ & $\mathrm{H}$ & $\mathrm{CH}_{3}$ & 886.5 & shellfish & metabolite \\
\hline AZA21 & a1 & H & $\Delta$ & $\mathrm{OH}$ & $\mathrm{H}$ & $\mathrm{CH}_{3}$ & $\mathrm{H}$ & $\mathrm{COOH}$ & $\mathrm{H}$ & $\mathrm{CH}_{3}$ & 888.5 & shellfish & metabolite \\
\hline AZA23 & a1 & H & $\Delta$ & $\mathrm{OH}$ & $\mathrm{CH}_{3}$ & $\mathrm{CH}_{3}$ & $\mathrm{H}$ & $\mathrm{COOH}$ & $\mathrm{H}$ & $\mathrm{CH}_{3}$ & 902.5 & shellfish & metabolite \\
\hline AZA26 & a2 & H & $\Delta$ & $\mathrm{H}$ & $\mathrm{H}$ & $\mathrm{CH}_{3}$ & . & . & . & . & 824.5 & shellfish & metabolite \\
\hline AZA29 & a1 & H & $\Delta$ & $\mathrm{H}$ & $\mathrm{H}$ & $\mathrm{CH}_{3}$ & $\mathrm{CH}_{3}$ & $\mathrm{H}$ & $\mathrm{H}$ & $\mathrm{CH}_{3}$ & 842.5 & shellfish & artefact \\
\hline AZABO & a1 & H & $\Delta$ & $\mathrm{H}$ & $\mathrm{H}$ & $\mathrm{CH}_{3}$ & $\mathrm{CH}_{3}$ & $\mathrm{CH}_{3}$ & $\mathrm{H}$ & $\mathrm{CH}_{3}$ & 856.5 & A. spinosum & artefact \\
\hline AZA32 & a1 & $\mathrm{H}$ & $\Delta$ & $\mathrm{H}$ & $\mathrm{CH}_{3}$ & $\mathrm{CH}_{3}$ & $\mathrm{CH}_{3}$ & $\mathrm{CH}_{3}$ & $\mathrm{H}$ & $\mathrm{CH}_{3}$ & 870.5 & A. spinosum & artefact \\
\hline AZA33 & b1 & H & $\Delta$ & - & - & $\mathrm{CH}_{3}$ & H & $\mathrm{CH}_{3}$ & $\mathrm{H}$ & $\mathrm{CH}_{3}$ & 716.5 & A. spinosum & phycotoxin \\
\hline AZA34 & c1 & H & $\Delta$ & - & - & $\mathrm{CH}_{3}$ & H & $\mathrm{CH}_{3}$ & H & $\mathrm{CH}_{3}$ & 816.5 & A. spinosum & phycotoxin \\
\hline AZA36 & a1 & H & $\Delta$ & $\mathrm{OH}$ & $\mathrm{CH}_{3}$ & $\mathrm{CH}_{3}$ & H & $\mathrm{CH}_{3}$ & H & $\mathrm{H}$ & 858.5 & A. poporum & phycotoxin \\
\hline AZA37 & a1 & H & . & $\mathrm{OH}$ & $\mathrm{H}$ & $\mathrm{CH}_{3}$ & H & $\mathrm{CH}_{3}$ & $\mathrm{H}$ & H & 846.5 & A. poporum & phycotoxin \\
\hline AZA38 & a1 & H & . & $\mathrm{CH}_{3}$ & $\mathrm{H}$ & $\mathrm{H}$ & H & $\mathrm{CH}_{3}$ & $\mathrm{H}$ & $\mathrm{H}$ & 830.5 & A. Ianquida & phycotoxin \\
\hline AZA39 & d1 & $\mathrm{CH}_{3}$ & . & $\mathrm{H}$ & . & $\mathrm{H}$ & $\mathrm{H}$ & $\mathrm{CH}_{3}$ & $\mathrm{H}$ & $\mathrm{H}$ & 816.5 & A. languida & phycotoxin \\
\hline AZA40 & a1 & $\mathrm{H}$ & $\Delta$ & $\mathrm{H}$ & $\mathrm{CH}_{3}$ & $\mathrm{CH}_{3}$ & $\mathrm{H}$ & $\mathrm{CH}_{3}$ & $\mathrm{H}$ & $\mathrm{H}$ & 842.5 & A. poporum & phycotoxin \\
\hline -AZA41 & a1 & $\mathrm{H}$ & $\Delta$ & $\mathrm{H}$ & $\mathrm{CH}_{3}$ & $\mathrm{CH}_{3}$ & $\mathrm{H}$ & $\mathrm{CH}_{3}$ & $\mathrm{H}$ & $\mathrm{CH}_{3}$ & 854.5 & A. poporum & phycotoxin \\
\hline
\end{tabular}

Compounds highlighted in grey have had their structures confirmed by NMR; "orientation of the methyl group at C37. The type refers to variations of the LHS and RHS parts of the molecule."Double bond in the nitrogen containing ring. 
Recently, two strains of Azadinium poporum, a species previously reported to be non-toxigenic (Potvin et al.2012; Tillmann et al. 2011), were proven to be the producers of two previously unknown AZAs (Krock et al. 2012). AZA37 from a North Sea isolate of A. poporum (Tillmann et al. 2011) with a molecular mass of $845 \mathrm{Da}$ ( $c a .10 \mathrm{fg} / \mathrm{cell}$ ) was determined as 39-desmethyl-7,8-dihydro-3-hydroxyAZA-1 by nuclear magnetic resonance (NMR) spectroscopy (Table $\underline{1}$; Kilcoyne et al. 2014c). The other strain of A. poporum, from Shiwha Bay, Republic of Korea (Potvin et al. 2012), produced AZA36 with a molecular mass of $857 \mathrm{Da}$ ( $c a .2 \mathrm{fg} / \mathrm{cell}$ ), which was determined as 39-desmethyl-3hydroxy-AZA-2 (Table 1). Both A. poporum-derived AZAs have a 3-hydroxy substitution and a 39desmethyl moiety in common.

Whereas the 3-hydroxy function is also found in shellfish metabolites of AZA1 and AZA2 (e.g., AZA4 and AZA9) (Kilcoyne et al. 2015), the 39-desmethyl moiety is unique to a new class of dinoflagellate AZAs. This new class of 39-desmethyl-AZAs is easily recognized in tandem mass spectrometry by a characteristic $m / z 348$ fragment, whereas all other AZAs have a $m / z 362$ fragment. Two additional AZAs with $m / z 348$ fragment and molecular masses of 815 and $829 \mathrm{Da}$ ( $c a .11$ and 6 $\mathrm{fg} \mathrm{cell}^{-1}$, respectively) were also identified in a strain of Amphidoma languida (Tillmann et al. 2012). AZAs were also detected in isolates of A. poporum from Chinese coastal waters ( $\mathrm{Gu}$ et al. 2013). Whereas one strain did not produce any AZAs, three other strains produced exclusively AZA2 at cell quotas ranging from 1.8 to $23 \mathrm{fg} / \mathrm{cell}$. In addition, new AZAs with the $m / z 348$ fragment were detected in a fifth strain, which also produced AZA36 (1.4 fg/cell). In contrast to the Korean strains, this Chinese strain produced AZAs (with the $m / z 348$ fragment) with molecular masses of 919 and $927 \mathrm{Da}$ ( ca. 0.02 and $0.14 \mathrm{fg} /$ cell, respectively). A sixth strain of A. poporum from China produced an AZA with a molecular mass of $871 \mathrm{Da}(0.9$ to $1.9 \mathrm{fg} / \mathrm{cell})$ that was tentatively identified as AZA11 by comparison of retention times and collision induced dissociation (CID) spectra (Gu et al. 2013). Whereas 3-hydroxylated AZAs like AZA36 and AZA37 seem to be biosynthesized by several strains of A. poporum, AZA11 may be the first case of an AZA being independently produced by dinoflagellate biosynthesis as well as through shellfish metabolic activity.

It is likely that several more analogues of this toxin group will be reported soon, as there are not yet many strains or species isolated from most regions. For instance, Azadinium dexteroporum, a new species recently isolated from the Mediterranean Sea (Italy), has also been reported to produce some novel analogues which have not yet been fully characterized (Percopo et al. 2013).

\section{Shellfish Metabolism}

To date, more than 30 AZA structural variants are known (Table 1). As the exact nomenclature of AZAs according to the rules of the International Union of Pure and Applied Chemistry (IUPAC) is long and complicated, AZAs have been named by numbering in the chronological order of their detection or postulation. All AZAs up to AZA23 were originally identified or postulated from shellfish; however, AZA1 and AZA2 are of dinoflagellate origin, whereas AZA4 to AZA23 have not been detected in planktonic samples and have been shown to be shellfish metabolites, with the exception of AZA11 (Gu et al. 2013; Rehmann et al. 2008).

Shellfish are known to transform AZAs by two different types of reactions: (1) hydroxylation at C3 and C23 and (2) carboxylation at C22 and subsequent decarboxylation (James et al. 2003b; Jauffrais et al. 2012c; Kittler et al. 2010; McCarron et al. 2009; O'Driscoll et al. 2011; Rehmann et al. 2008). Recent investigations with feeding experiments (Jauffrais et al. 2012c; Salas et al. 2011) revealed that blue mussels ( Mytilus edulis) metabolize AZAs quickly. AZA17 and AZA19 were the most abundant metabolites of AZA1 and AZA2, respectively, suggesting that carboxylation of the methyl group at 
C22 is a preferred metabolic pathway (Jauffrais et al. 2012c). Hydroxylation and decarboxylation seem to be secondary degradation routes (McCarron et al. 2009).

Hydroxylations of AZAs by shellfish metabolism occur at $\mathrm{C} 3$ on the carboxylic acid side chain to form 3-hydroxy-AZAs (e.g., AZA7, AZA11) as well as at C23 at the E-ring of the molecule, resulting in 23-hydroxy-AZAs (AZA8, AZA12) (Table 1). Furthermore, the methyl group at C22 can be oxidized to 22-carboxy-AZAs (AZA17, AZA19), which are subsequently decarboxylated to form the 22-desmethyl-AZAs (AZA3, AZA6) (McCarron et al. 2009; O'Driscoll et al. 2011). AZA 22decarboxylation may be a shellfish metabolic activity; however, this reaction occurs rapidly during heating of shellfish meat and slowly in extracts stored at ambient temperature (McCarron et al. 2009). In addition, combinations of these processes are possible, to produce many of the remaining AZAs (AZA4, AZA5, AZA9, AZA10, AZA13, AZA14, AZA15, AZA16, AZA21, and AZA23). Some of the other AZAs originally detected without structural elucidation were later identified as extraction artifacts (AZA29, AZA30, and AZA32) (Jauffrais et al. 2012a). In contrast to shellfish metabolism, phase I metabolites of AZA1 using rat liver microsomes (S9 mix) included an oxidation of the F-ring of the molecule, which is not observed in shellfish metabolites. Glucuronides were found as the only phase II metabolites of AZA1, and via precursor ion experiments, it could be proven that glucuronic acid is bound to AZA1 at C1 via an ester linkage (Kittler et al. 2010).

One study reported on binding of AZAs to proteins (Nzoughet et al. 2008) found that AZAs in mussel hepatopancreas bind to as yet unidentified proteins with molecular masses of 21.8 and $45.3 \mathrm{kDa}$.

\section{Chemical Degradation Products and Artifacts}

Among the modifications of AZA profiles due to extraction and/or sample processing are (1) epimerization, (2) 22-decarboxylation, and (3) formation of methyl derivatives.

Isomers of AZAs have previously been reported which were produced as a result of degradation of the main analogues in acidic environments (Alfonso et al. 2008; Rehmann et al. 2008). The development of a neutral method led to the discovery of isomers of AZAs which were not resolved at low $\mathrm{pH}$ (McCarron et al. 2011). These isomers recently identified as 37- epi-AZAs are spontaneous epimerization products whose formation is accelerated with heat, with proportions ranging from $2 \%$ to $15 \%$ of their parent analogues (Kilcoyne et al. 2014a). As most biosynthetic processes are stereospecific, it can be assumed that only one enantiomer is produced by the organism. Similar occurrences are known from paralytic shellfish poisoning (PSP) toxins, where only the energetically less-favored betamers are produced, which slowly epimerize to the more stable alphamers until equilibrium distribution (Cembella 1998). The formation of the 22-desmethyl-AZAs (AZA3, AZA4, AZA6, and AZA9) following heat treatment was demonstrated, and it was shown that these AZAs result from decarboxylation of their 22-carboxylated progenitors (McCarron et al. 2009). Even though it has been clearly shown that this decarboxylation is a thermally accelerated reaction, the 22desmethyl-AZAs can be detected in lower amounts in fresh, uncooked shellfish indicating that this reaction proceeds even at lower temperatures (McCarron et al. 2007, 2009).

In contrast, methyl esters and 21-methyl ketals of AZAs are clearly artifacts. The methylation of AZAs easily occurs if methanol is used for extraction of algal biomass or as a sample storage solvent for such extracts (Jauffrais et al. 2012a). The methylation is a relatively slow process at low temperatures but is promoted by high temperatures and alkaline or acidic conditions. For instance, planktonic field samples that were extracted with methanol and stored in the same solvent at $-20{ }^{\circ} \mathrm{C}$, after 5 years, displayed more than $50 \%$ of the total AZA content as methyl esters (Krock et al. 2012). However, methyl esters can be detected in relatively fresh methanolic extracts of AZA-containing samples. For example, the reported isomer of AZA2 in A. spinosum (Tillmann et al. 2009) was later 
identified as AZA1 methyl ester. Consequently, the use of methanol as extraction solvent may be avoided and replaced by acetone or aqueous acetonitrile, if analysis for AZAs is of special concern (Kilcoyne et al. 2012).

\section{Producing Organisms}

As described above, four of the currently known 12 species of Amphidomataceae have toxinproducing strains (Tillmann et al. 2014): A. spinosum, A. poporum, A. dexteroporum, and A. languida. This does not mean that further studies will not change this picture as for several species only one strain has been isolated so far. Due to the fact that a number of strains of these species have been found in many areas of the globe (Europe, Australasia, America), ubiquitous distribution of the genus is likely. This is also coherent with increasing reports of toxins identified in many seafood or marine organisms or marine environmental samples.

\section{Vectors of Poisoning}

The main vector of AZP is mussels ( Mytilus edulis), as all reported shellfish poisoning incidents have been related to shellfish from mussels originating from Irish coastal waters (EFSA 2008; Salas et al. 2011; Twiner et al. 2014). However, other shellfish species, including Japanese and flat oysters ( Crassostrea gigas and Ostrea edulis) and razor fish ( Ensis siliqua), have also been shown to be contaminated with AZAs (Hess 2002). Furthermore, scallops ( Pecten maximus and Argopecten purpuratus) have also been shown to be contaminated with AZAs and cannot, in principle, be excluded as potential vectors (López-Rivera et al. 2010; Magdalena et al. 2003b). Furthermore, it should be noted that crustaceans, such as crabs ( Cancer pagurus), may accumulate AZAs due to their feeding on contaminated mussels (Torgersen et al. 2008). Although in that particular event the accumulation had not led to human poisoning, such a vector cannot be excluded as it had previously been shown that consumption of contaminated crabs may lead to poisoning with a similar lipophilic toxin group: OA (Torgersen et al. 2005). The occurrence of toxins in crustaceans is still an underestimated risk as European and other international legislation do not require monitoring of crustaceans for algal toxins.

\section{Epidemiological Data}

The first confirmed AZP event occurred in November 1995. Mussels harvested from Killary Harbour, Ireland, were exported to the Netherlands, resulting in eight people falling ill with DSP-like symptoms of gastrointestinal illness, including nausea, vomiting, severe diarrhea, and stomach cramps (Furey et al. 2010; McMahon and Silke 1996; Satake et al. 1998a, $\underline{b}$ ). The absence of known DSP toxins OA and DTX2 led to the discovery and identification of a novel etiological agent, temporarily called Killary Toxin-3 before being renamed to AZA1 (Satake et al. 1998b). Mussels collected from the same area 5 months after the event were shown to contain (in $\mu \mathrm{g} / \mathrm{g}$ whole meat) AZA1 (1.14), AZA2 (0.23), and AZA3 (0.06) (Ofuji et al. 1999; Ryan et al. 2008).

In September-October 1997, as few as 10-12 AZA-contaminated mussels were consumed by individuals in the Arranmore Island region of Donegal, Ireland. At least 20-24 people were believed to have been exposed to AZAs in this event, but only eight sought medical attention. Symptoms included nausea, vomiting, and diarrhea for 2-5 days prior to full recovery. Analysis of the shellfish 
revealed five AZA analogues, AZA1-5, with most of the toxin concentrated in the digestive glands (Ofuji et al. 1999, 2001) at levels exceeding $30 \mu \mathrm{g} / \mathrm{g}$ (estimated at $6 \mu \mathrm{g} / \mathrm{g}$ whole mussel meat) (Furey et al. 2010). The AZAs persisted in the mussels at elevated levels for at least 8 months (Furey et al. 2010).

In September 1998, mussels exported from Clew Bay, Ireland, to Ravenna, Italy, were consumed, and ten people fell victim to AZP with typical gastrointestinal symptoms. Digestive glands were shown to contain $c a .1 \mu \mathrm{g} / \mathrm{g} \mathrm{AZA}$ total with three AZA analogues present (in $\mu \mathrm{g} / \mathrm{g}$ digestive gland): AZA1 (0.5), AZA2 (0.06), and AZA3 (0.44) (Furey et al. 2010).

Also in September 1998, a large shipment of mussels from Bantry Bay, Ireland, was sent to France, resulting in an estimated 20-30 human illnesses due to AZP. Ironically, these shellfish had been deemed safe according to the DSP mouse bioassay; however, it was later determined that the DSP mouse bioassay is susceptible to false negatives for the AZA toxins. Coincidently, the French government posed an embargo on the import of Irish shellfish for most of 1999. Follow-up analysis of the shellfish by LC/MS determined that high levels of AZA were present (up to $1.5 \mu \mathrm{g} / \mathrm{g}$ whole meat) (Furey et al. 2010).

In August 2000, between 12 and 16 people from various regions (Warrington, Aylesbury, Isle of Wight, Sheffield) of the United Kingdom were intoxicated following the consumption of frozen, precooked mussels that originated from Bantry Bay, Ireland. Symptoms included nausea, diarrhea, abdominal pain, and cramps (Ryan et al. 2008). These mussels were also deemed safe for human consumption based on results from mouse bioassays; however, LC/MS analysis determined the presence of AZA1-3 in an uneaten portion from this same batch. Toxin concentrations were $0.85 \mu \mathrm{g} / \mathrm{g}$ shellfish meat (not including the digestive gland), which likely represented an underestimation of the total concentration (Furey et al. 2010).

No other AZP events occurred until 2008 when there were two events. In April 2008, many people in France fell ill due to AZP following the consumption of contaminated frozen, precooked mussels from Ireland. This event was categorized by the French government as a "large outbreak" that paralleled a separate incident of salmonellosis (RASFF 2008). Unfortunately, these contaminated shellfish were accidently released onto the consumer market after being identified as containing unsafe levels of AZA toxins and stored in quarantine (Furey et al. 2010).

The second 2008 AZP event occurred in the United States in July. Frozen, precooked mussels from Bantry Bay, Ireland, were exported and intoxicated two people. It is estimated that each person ate between 113 and $340 \mathrm{~g}$ of shellfish. Within $5 \mathrm{~h}$ following the meal, each person experienced abdominal heaviness, vomiting (5-15 times), and diarrhea for up to $30 \mathrm{~h}$. Analysis of similar products with the same lot number revealed the presence of AZA1-3 with up to $0.244 \mu \mathrm{g} \mathrm{AZA}_{\text {total }} / \mathrm{g}$ tissue (Klontz et al. 2009). As a result of this event, over 150 tonnes of commercial product were removed from the market and voluntarily destroyed by the manufacturer (R. Dickey, pers. comm.). Due to the limited epidemiological data available from the abovementioned human AZP events, nearly all information regarding AZA toxicology has been obtained from controlled in vitro and in vivo experiments. Many of these efforts have been directed toward assessing the risk of AZA consumption in contaminated shellfish and accompanied by intensive, wide-ranging studies aimed at identifying the molecular target(s) of AZA.

\section{Toxicokinetics}




\section{Experimental Data}

\section{"In Vivo" Experimental Data}

After acute oral administration by gavage of sublethal doses of AZA1 to mice (100-300 $\mu \mathrm{g} / \mathrm{kg})$, a dose-dependent increase of the toxin levels was observed in different tissues. At $24 \mathrm{~h}$ from the toxin administration, the total amount of AZA1 in the internal organs was only about $2 \%$ of the administered doses, with the highest distribution in the liver, followed by kidneys, lungs, spleen, and heart. Considering the toxin concentrations, the highest levels were detected in the stomach and duodenum, followed by kidneys and spleen, lungs, jejunum, heart, liver, ileum, colon, blood, and only traces in the brain. The renal concentration of AZA1 remained almost unchanged after 7 days, suggesting a toxin transport from the other organs to the kidneys (Aasen et al. 2010, 2011). Following the administration of higher doses of AZA1 (660-1140 $\mu \mathrm{g} / \mathrm{kg})$, the highest toxin levels were found in the stomach, and lower levels were detected, in descending order, in the duodenum, jejunum, ileum, and colon. The highest concentrations in the internal organs were in the spleen, lungs, and kidneys, followed by lower levels in the liver, thymus, and heart, while low concentrations were found in the blood (Aune et al. 2012).

Recently, the comparative distribution of AZA1, AZA2, and AZA3 was evaluated in the main internal organs of mice, $24 \mathrm{~h}$ after gavage and after 14 days of toxin withdrawal. A dose dependency in AZA1-3 absorption from the gastrointestinal tract was observed, and the pattern of toxin distribution was very similar among the three toxins. At $24 \mathrm{~h}$, the highest AZA levels were detected in the stomach and, in descending order, in the intestinal content, liver, small intestine, kidneys, lungs, large intestine, heart, and brain. Recoveries were $c a .6-23 \%$ for AZA1 and $c a .4-19 \%$ for AZA2 and were lower for AZA3 ( ca. 2-8 \%) after $24 \mathrm{~h}$. After 14 days from AZA administration (300 or $500 \mu \mathrm{g} / \mathrm{kg}$ ), only AZA1 and AZA2 were still detectable in the internal organs, with a total recovery lower than 3 $\%$ (Tubaro et al. 2014).

The influence of other marine algal toxins (yessotoxin or OA) on AZA1 distribution in the main internal organs of mice was also investigated after their single oral co-administration. Oral coadministration of yessotoxin ( 1 or $5 \mathrm{mg} / \mathrm{kg})$ and AZA1 $(200 \mu \mathrm{g} / \mathrm{kg})$ to mice did not influence the toxin absorption as compared to the absorption of each toxin alone (Aasen et al. 2011). On the contrary, oral co-exposure to AZA1 $\left(570 \mu \mathrm{g} / \mathrm{kg}\right.$, corresponding to its $\mathrm{LD}_{10}$ determined in the same study) and the diarrhetic toxin OA ( 780 or $880 \mu \mathrm{g} / \mathrm{kg}$, the toxin $\mathrm{LD}_{10}$ and $\mathrm{LD}_{50}$ in the same study) resulted in a very low absorption of each toxin from the gastrointestinal tract, even lower than that recorded after the administration of each toxin alone (Aune et al. 2012).

\section{"In Vitro" Experimental Data}

To evaluate the liver metabolism of AZA1, an in vitro study was carried out incubating the toxin with a fraction from rat liver homogenate ( $\mathrm{S} 9$ fraction) and supplemented co-factors. The study demonstrated that the toxin is converted into oxygenated phase I metabolites, including two dehydrogenated derivatives. In terms of phase II metabolism, only the conjugation of glutathione and glucuronidation were investigated; they observed conjugations to glucuronic acid but not glutathione adduct formation (Kittler et al. 2010). 


\section{Human Data}

No data on toxicokinetics (i.e., absorption, metabolism, distribution, and elimination) of AZAs in humans are available.

\section{Mechanisms of Action}

Since the AZA toxin class has been identified as a unique algal toxin group, many targets and mechanisms have been proposed and tested. Based on the similarities in gastrointestinal symptoms that AZAs have in common with the DSP toxins (OA and DTXs), known protein phosphatase (PP) inhibitors, AZAs were originally classified together with the DSP toxins (Twiner et al. 2008). As such, it was first postulated that the most likely mechanism of action was PP inhibition (Flanagan et al. 1999). PPs are well-described regulators of cell signaling pathways where they act in a manner opposite to that of kinases by removing phosphate groups from proteins. The serine/threonine PPs are known to be inhibited by OA (Cohen 1989). However, the effects of crude blue mussel extracts containing AZAs demonstrated no indication of PP1 enzyme inhibition (Flanagan et al. 2001), and a subsequent study utilizing the same assay format but with PP2A also found no effects of purified AZA1 on enzyme activity (Twiner et al. 2005). Furthermore, the AZAs have been subsequently tested against a non-receptor phosphotyrosine PP (PTP1B) and a T cell protein tyrosine phosphatase (TCPTP) with no change in enzyme activity (M. Twiner, unpublished data). Collectively, these data suggest that the AZA toxins are not PP inhibitors.

Not unlike PPs, cellular kinases play a very important role in cell communication, signaling, metabolism, and cell death. In particular, mitogen-activated protein kinases (MAPKs) present a multitude of different pathways and play crucial roles in the regulation of cell death and survival induced by several mechanisms. Although the AZA cytotoxicity response was not altered by inhibitors of extracellular signal-regulated kinase (ERK) or p38 MAPK, cytotoxicity was reduced in the presence of a c-Jun N-terminal protein kinase (JNK) inhibitor (Vale et al. 2007) that corresponds to JNK activation (Vale et al. 2010). However, this phenomenon may only be restricted to primary cerebellar granular cells (CGCs) as it was not observed in neocortical neurons (Cao et al. 2010). In a similar manner, the cAMP pathway and protein kinase $\mathrm{C}$ and phosphatidylinositol 3-kinase were ruled out as possible targets (Vale et al. 2007). Furthermore, AZAs were tested on 40 additional kinases without any indication of inhibition (Twiner et al. 2014) strongly suggesting that AZAs are not kinase inhibitors.

Following the observation that AZAs are potent cytotoxic agents and cause extensive morphological and cytoskeletal changes to cultured cells (Twiner et al. 2005, 2012b), the effects of AZAs on actin were assessed. However, AZAs did not directly alter actin polymerization or depolymerization in vitro (Twiner et al. 2014) suggesting that intracellular cytoskeletal rearrangements mediated by AZA toxins are likely an indirect or downstream effect of a toxicological response.

In cultured neurons, AZA was tested for its effects on neurotransmitter release. AZA1 did not have any effect on cholinergic, purinergic, or ionotropic receptors, i.e., gamma-aminobutyric acid (GABA A) (Vale et al. 2010). However, the effects of AZA1 on bioelectrical activity of spinal cord neurons were enhanced in the presence of a GABA ${ }_{A}$ inhibitor (Kulagina et al. 2006). AZAs were also tested for its effects on $76 \mathrm{G}$ protein-coupled receptors (GPCRs), but none of these were altered (stimulated or inhibited) (Twiner et al. 2014), essentially ruling out GPCRs as an AZA target.

There are ample publications available that demonstrate AZA toxins alter ion flux in various cell types. The AZAs have been shown to alter intracellular calcium flux (Roman et al. 2002), proton homeostasis (Alfonso et al. 2006), and membrane hyperpolarization (Vale et al. 2010). In CGCs, 
anion channel blockers and ouabain greatly ameliorated the cytotoxic effect of AZA1 in immature neurons and completely eliminated it in older cultures (Vale et al. 2010). Furthermore, short exposures of cultured neurons to AZA1 caused a significant decrease in neuronal volume that was reduced by preincubation of the neurons with a chloride channel blocker or amiloride $\left(\mathrm{Na}^{+}-\mathrm{K}^{+}-\right.$ ATPase blocker) (Vale et al. 2010). In neocortical neurons, voltage-gated sodium channels (VGSCs), $\mathrm{N}$-methyl- d-aspartic acid (NMDA), glutamate receptors, and L-type $\mathrm{Ca}^{2+}$ channels were not observed to play a role in AZA1-induced neurotoxicity, which is consistent with reports that AZA1 alone does not affect VGSC (Kulagina et al. 2006; Twiner et al. 2014). However, a recent study demonstrated that AZAs in the presence of glutaric acid (also found at significant concentrations in shellfish areas known for AZP events) inhibited sodium current through $\mathrm{Na}_{\mathrm{v}} 1.6$ channels (Chevallier et al. 2015) opening up the possibility that co-occurring secondary compounds may play a synergistic role in AZA toxicity. Nonetheless, AZAs have been shown to inhibit hERG (human ether-à-go-go-related gene) channels, a specific type of potassium ion channel (Twiner et al. 2012a). hERG channels are important in the cardiac action potential by mediating the "rapid" delayed rectifier current $\left(I_{\mathrm{Kr}}\right)$ (Sanguinetti and Tristani-Firouzi 2006) that plays a significant role during the repolarization phase where alternations of this channel can lead to long QT syndrome and sudden cardiac death. Subsequent in vitro exposure studies demonstrated AZA2 caused an increase in the levels of membrane hERG channels without a change in potassium current through the channel (Ferreiro et al. 2014b). Electrocardiogram (ECG) studies in rats showed arrhythmic electrical activity including prolonged PR intervals consistent with second- and third-degree heart block but without a prolonged QT (Ferreiro et al. 2014a) clearly demonstrating cardiotoxicity and the need for follow-up studies. In summary, AZAs do not appear to be inhibitors of PP, kinases, and GPCRs or inhibit actin polymerization/depolymerization, but they have been shown to be cytotoxic, affect cytoskeleton arrangements, and inhibit potassium channels (hERG) and voltage-gated sodium channels $\left(\mathrm{Na}_{\mathrm{v}}\right.$ 1.6; in the presence of glutaric acid). Inhibition of these ion channels may prove to account for the cardiotoxicity observed in rats. However, at this point in time, there does not yet appear to be a scientific consensus regarding a particular target or mechanism for the AZA toxin class that can jointly account for the wide array of effects that have been experimentally observed and the gastrointestinal symptoms observed in exposed humans.

\section{Toxicity}

\section{Human Toxicity}

Human consumption of AZA-contaminated seafood induces an acute illness characterized by gastrointestinal symptoms, which occur within hours and include nausea, vomiting, severe diarrhea, and stomach cramps. The symptoms persist for 2-3 days, and, to date, no long-term effects have been reported (James et al. 2004; Twiner et al. 2008). On the basis of information from one incident in humans, the European Food Safety Authority (EFSA) Panel on contaminants in the food chain (CONTAM Panel) estimated $113 \mathrm{~g}$ AZA1 equivalents/person as the most probable lowest-observedadverse-effect level (LOAEL) resulting in AZP, which corresponds to $1.9 \mu \mathrm{g}$ AZA1 equivalents $/ \mathrm{kg}$ for a person of $60 \mathrm{~kg}$ body weight. These values were used to establish the acute reference dose (ARfD), equal to $0.2 \mu \mathrm{g}$ AZA1 equivalents/kg body weight (EFSA $\underline{2008}$ ). 
Considering a possible risk of chronic effects due to repeated consumption of seafood contaminated by low levels of AZAs, the scarcity of epidemiological data does not allow for establishing any link between AZA exposure and the occurrence of long-term adverse effects, such as cancer or birth defects in humans (Twiner et al. 2008).

\section{Experimental Toxicity}

In vivo toxicological studies on AZAs are limited due to the low availability of pure toxins, and the first studies had been carried out using shellfish extracts contaminated by AZA1.

\section{Single Administration}

The first evidence of acute AZA toxicity following intraperitoneal (i.p.) administration in mice was recorded after injection of acetone extracts from contaminated mussels which caused "neurotoxinlike" symptoms, including sluggishness, dyspnea, spasms, progressive paralysis, and death within less than 1-2 h. Subsequently, the lethal intraperitoneal dose in mice of purified AZA1 has been estimated at $200 \mu \mathrm{g} / \mathrm{kg}$ (Satake et al. 1998b). AZA1 was less toxic than AZA2 and AZA3 (lethal dose, 110 and $140 \mu \mathrm{g} / \mathrm{kg}$ for AZA2 and AZA3, respectively) and more toxic than AZA4 and AZA5 (lethal dose, $c a$. $470 \mu \mathrm{g} / \mathrm{kg}$ and $<1 \mathrm{mg} / \mathrm{kg}$ for AZA4 and AZA5, respectively) (Ofuji et al. 1999, 2001). However, due to the scarcity of pure toxins, the lethal doses were determined using a low number of animals, and the information provided by these data should be considered only as indicative (EFSA 2008).

Nevertheless, the i.p. lethal doses of AZA1, AZA2, and AZA3, the three AZAs regulated at European Union level, have been used to derive their toxic equivalency factors (TEF, 1.0, 1.8, and 1.4 for AZA1, AZA2, and AZA3, respectively), currently adopted to convert the amounts of individual toxins to AZA1 equivalents during the estimation of total AZAs in edible shellfish (EFSA 2008; Twiner et al. 2008). Signs and symptoms observed in mice after i.p. injection of purified AZAs included progressive paralysis of the limbs, dyspnea, and convulsions before death (Furey et al. 2010; Twiner et al. 2008).

Recently, AZA2 was investigated for its effects on electrocardiogram (ECG) and cardiac biomarkers, after intravenous injection in rats . The toxin (11 or $55 \mu \mathrm{g} / \mathrm{kg}$ ) did not induce QT interval prolongation on rat ECGs, in spite of being an in vitro blocker of the hERG cardiac potassium ion channels, and did not increase the plasma levels of selected biomarker indices of acute myocardial damage.

Nevertheless, both the doses of AZA2 altered the cardiac electrical activity in some rats, prolonging PR intervals (4/8 and 1/2 rats at the low and high doses, respectively) and altering the cardiac rhythm ( $3 / 8$ and $2 / 2$ rats at the low and high doses, respectively). Even though more studies are needed to clarify these effects, the potential cardiac toxicity of AZAs should be considered as possible threat for human health, particularly for subjects with cardiovascular diseases (Ferreiro et al. 2014a). After oral administration of AZA1 ( $\geq 300 \mu \mathrm{g} / \mathrm{kg}$ ) to mice by gavage, Aune et al. (2012) recorded lethal effects within $24 \mathrm{~h}$ at the dose of $600 \mu \mathrm{g} / \mathrm{kg}$, estimating an $\mathrm{LD}_{50}$ (lethal dose for $50 \%$ of the treated animals) of $775 \mu \mathrm{g} / \mathrm{kg}$. Other studies recorded lethal effects at doses ranging from 250 to $>700$ $\mu \mathrm{g} / \mathrm{kg}$ (Aasen et al. 2010, 2011; Ito et al. 2000, 2002, 2006), with individual differences in sensitivity to AZA1 and age-dependent lethality (Ito et al. 2002). In a more recent comparative acute oral toxicity study on AZA1-3 in mice, lethality was recorded at a lower dose of AZA1 (230 $\mu \mathrm{g} / \mathrm{kg}), 500$ $\mu \mathrm{g} / \mathrm{kg}$ of AZA2, and $650 \mu \mathrm{g} / \mathrm{kg}$ of AZA3, whereas their LD ${ }_{50}$ based on $24 \mathrm{~h}$ lethality data were 443 , 626 , and $875 \mu \mathrm{g} / \mathrm{kg}$, respectively. Thus, the acute oral toxic potency is AZA1 > AZA2 > AZA3, and, giving a reference value of 1.0 to AZA1, the relevant TEFs based on $\mathrm{LD}_{50}$ correspond to 1.0 (AZA1), 
0.7 (AZA2), and 0.5 (AZA3) (Tubaro et al. 2014). These values are different from those currently adopted to quantify total AZAs in edible shellfish, derived after i.p. AZA injection in mice (EFSA 2008; Twiner et al. 2008).

Before death, common symptoms and signs of toxicity recorded in mice orally treated with AZA1, AZA2, or AZA3 included immobility, laying in sternal recumbence without moving, tremors, abdominal breathing, hypothermia, and cyanosis. Although diarrhea is the main sign of toxicity in humans after ingestion of AZA-contaminated seafood, oral exposure to AZA1-3 did not cause visible diarrhea in mice (Aune et al. 2012; Tubaro et al. 2014).

Acute oral toxicity studies on AZA1 in mice resulted in multiple organ damage, with three main targets: (i) gastrointestinal tract, with erosions of villi in the duodenum; (ii) liver, with fatty changes and single-hepatocyte necrosis; and (iii) lymphoid tissues, with necrotic lymphocytes in the thymus, spleen, and Peyer's patches. In particular, after sublethal oral dose administration (100-300 $\mu \mathrm{g}$ AZA1/kg), macroscopic or microscopic changes were noted only in the gastrointestinal tract and liver of mice. Within 4-24 h from the administration, the toxin induced stomach constipation, fluid accumulation in the upper small intestine, and tissue alterations in the duodenum (mild cellular detachment in the tips of the villi, expansion of the crypts, necrotic/apoptotic changes in the lamina propria with neutrophilic infiltration), which recovered within 7 days (Aasen et al. 2010, 2011; Ito et al. $\underline{2000}$ ). Moreover, at $300 \mu \mathrm{g} / \mathrm{kg}$, Ito et al. ( $\underline{2000}$ ) noted the accumulation of fat droplets in the liver of mice after $1 \mathrm{~h}$ which became progressively clear, changing the dark red color of the liver to pinkish red after $4 \mathrm{~h}$. At higher oral doses (420-900 $\mu \mathrm{g}$ AZA1/kg), pathological findings were recorded also in lymphoid tissues, in addition to the liver and gastrointestinal tract. Necropsy highlighted a pale liver after 1-24 h, while fatty changes in the hepatocytes were observed by light microscopy. After 10-30 h, material retention in the stomach (up to around four times in weight relative to controls) and watery content in the upper and middle small intestine were macroscopically evident (Aune et al. 2012). Histological analysis of the small intestine after $8 \mathrm{~h}$ showed tissue changes (degeneration of epithelial cells, erosions of villi, and necrosis of the lamina propria), even though signs of recovery were noted after $24 \mathrm{~h}$. There were also time- and dose-dependent necrotic T and B lymphocytes in the thymus, spleen, and Peyer's patches of the small intestine. At 600 and $700 \mu \mathrm{g} / \mathrm{kg}$, a significant decrease in the number of non-granulocytes (lymphocytes, monocytes, and macrophages) was quantified in the spleen (Aune et al. 2012; Ito et al. 2000, 2006).

The acute oral toxicity in mice of eight synthetic AZA1 analogues (6-, 10-, 13-, 14-, 16-, 17-, 19-, and 20- epi-AZA1) and twelve AZA1 fragments in comparison to synthetic AZA1 (doses, 0.5-3 mg/kg) had also been evaluated (Ito et al. 2006). Only AZA1 and its diastereoisomer $\mathrm{C}_{1}-\mathrm{C}_{20}$ - epi-AZA1 exerted significant toxicity, the latter being only one-fourth as toxic as AZA1. This finding suggests that the entire AZA1 molecule and its stereospecific orientation are necessary to exert the toxic effects.

Other toxicity studies evaluated the effects of single oral co-administration of AZA1 and other algal toxins that may co-occur in edible shellfish, with possible interaction between these compounds and consequent influence of the respective toxicities. Thus, the effects of single oral co-exposure to AZA1 and two structurally different marine algal toxins (yessotoxin or $\mathrm{OA}$ ) were studied in mice. The combined oral administration of AZA1 (200 $\mu \mathrm{g} / \mathrm{kg}$ ) and yessotoxin (1 or $5 \mu \mathrm{g} / \mathrm{kg})$, a dinoflagellate polyether previously shown to induce in vivo ultrastructural changes in cardiomyocytes of mice, provoked only the gastrointestinal alterations recorded after AZA1 alone administration. Thus, the oral co-exposure to AZA1 and yessotoxin did not result in enhanced toxic effects with respect to those of the single toxins (Aasen et al. 2011). Similarly, co-administration of AZA1 $(570 \mu \mathrm{g} / \mathrm{kg}$, corresponding to its $\mathrm{LD}_{10}$ determined in the same study) and OA (780 or $880 \mu \mathrm{g} / \mathrm{kg}$, the toxin $\mathrm{LD}_{10}$ 
and $\mathrm{LD}_{50}$ in the same study) did not result in additive or synergistic toxic effects, which were restricted to the gastrointestinal tract (Aune et al. 2012).

\section{Repeated Administration}

The effects of repeated oral doses of AZA1 were evaluated relatively early in mice, and the animals had been monitored for recovery of tissue injuries for up to 90 days after toxin withdrawal (Ito et al. 2002). In particular, groups of two and three mice were orally administered with 300 or $350 \mu \mathrm{g}$ AZA1/kg 3 days before a second oral dose of 300 or $250 \mu \mathrm{g} / \mathrm{kg}$, respectively. Similarly, a group of five out of 16 mice that survived after the treatment with $450 \mu \mathrm{g} / \mathrm{kg}$ were administered after 3 days with a second oral dose of 300,350 , or $450 \mu \mathrm{g} / \mathrm{kg}$. A mouse treated with $450 \mu \mathrm{g} / \mathrm{kg}$ followed by 350 $\mu \mathrm{g} / \mathrm{kg}$ died after the second administration, while the other nine surviving mice were sacrificed between 7 and 90 days post treatment to evaluate the recovery of organ injury. Tissue injuries, recorded in the liver, lymphoid tissues, lungs, and gastrointestinal tract, recovered after different times from toxin withdrawal. The fatty changes in the liver recovered after 7 days, but single-cell necrosis, swollen cells, and inflammatory cells were still present. After 10 days, polynuclear giant cells enclosing debris were noted around the central vein, where they were still noted together with small granulomas after 15 days, even at much less extent. A faster recovery was noted in the lymphoid tissues: although signs of atrophy and some inflammatory cells were still noted in the thymus and spleen after 10 days, necrotic cells were absent, while after 10 days the tissue changes became indiscernible. At pulmonary level, infiltration of cells in the alveolar wall was observed up to 8 weeks. Tissue injuries in the gastrointestinal tract were the most persistent. Mild erosions, often accompanied by active mucus secretion and bacterial infection, were sporadically noted in the stomach even after 90 days. In the small intestine, deformed villi with double-triple heads were often noted after 10-20 days from the first administration. The heights of the villi recovered to normal levels after 3 months, even though epithelial cells did not completely cover their tops (Ito et al. 2002).

Ito et al. ( 2002) also evaluated the effects in mice of low oral doses of AZA1 $(1-50 \mu \mathrm{g} / \mathrm{kg})$, administered $c a$. twice a week, up to 40 times for a period of 145 days. Surviving mice were kept alive up to 3 months after withdrawal to evaluate the progression of the toxin effects. At the doses of 50 and $20 \mu \mathrm{g} / \mathrm{kg}$, a marked weight loss was recorded mainly after 30 treatments so that mice appearing too weak to survive were sacrificed before the scheduled 40 administrations $(9 / 10$ after 18 40 treatments at $50 \mu \mathrm{g} \mathrm{AZA1} / \mathrm{kg}$ and 3/10 mice after 32-36 treatments at $20 \mu \mathrm{g} / \mathrm{kg}$ ). In these mice, the weight of different organs (heart, liver, kidneys, spleen, and thymus) was reduced in comparison to control mice. The main pathological changes in the weakened mice were recorded in the small intestine (shortened villi and reduced surface area for nutrient absorption) and lungs (interstitial pneumonia). Other pathological changes were recorded at gastric level (swollen stomachs, mild erosions in the mucosa, and sticky gastric juice secretion), spleen, and thymus (narrowed areas of red pulp, decreased lymphocytes, and neutrophil infiltration). On the other hand, no severe injuries were recorded in the liver (only few mice showed focal necrosis, single-cell necrosis, minor inflammation, mitosis, and congestion), contrary to the observations at higher doses, after single or double administration.

Considering also the mice sacrificed after the withdrawal, a low incidence of lung tumor formation and gastric hyperplasia was recorded. Lung tumors were observed in four mice: one at $50 \mu \mathrm{g} / \mathrm{kg}$ (after 32 treatments) and three at $20 \mu \mathrm{g} / \mathrm{kg}$ (one after 36 treatments and the other 2 and 3 months after withdrawal). Hyperplasia in the gastric mucosa was recorded in six mice administered with $20 \mu \mathrm{g}$ AZA1/kg (one after 32 treatments and five in post withdrawal periods). At the end of 3 months of 
withdrawal, the lamina propria of the small intestinal villi showed atrophy, and many villi had open tops indicating incomplete recovery (Ito et al. 2002).

No signs of toxicity were noted in mice administered with 1 and $5 \mu \mathrm{g}$ AZA1/kg. Nevertheless, one out of five mice exposed to $5 \mu \mathrm{g}$ AZA1/ $\mathrm{kg}$ showed constipation after more than 2 months of toxin withdrawal, probably due to ulceration and perforation of the digestive tube, while all five mice treated at the same dose had small intestinal erosions attributed to unhealed injuries. In addition, after 3 months of recovery, 1/6 mice dosed with $1 \mu \mathrm{g}$ AZA1/kg showed a hyperplasic nodule in the liver, surrounded by many mitotic cells (Ito et al. 2002).

Ito et al. (2004) further investigated the potential AZA1 carcinogenicity after repeated oral administration to groups of 10-23 mice, at doses up to $20 \mu \mathrm{g} / \mathrm{kg}$. Group 1 was administered with 20 $\mu \mathrm{g} / \mathrm{kg}$ (twice a week, 40 doses), group 2 received $20 \mu \mathrm{g} / \mathrm{kg}$ (twice a week, 33 doses), group 3 received $5 \mu \mathrm{g} / \mathrm{kg}$ (twice a week, 40 doses), group 4 received $10 \mu \mathrm{g} / \mathrm{kg}$ (once a week, 20 doses), and group 5 was administered with $5 \mu \mathrm{g} / \mathrm{kg}$ (once a week, 20 doses). The doses in groups 1 and 2 were changed depending on the health condition of mice as follows: group 1 (17 treatments at $20 \mu \mathrm{g} / \mathrm{kg}$ and 23 treatments at $10 \mu \mathrm{g} / \mathrm{kg}$ ) and group $2(13$ treatments at $20 \mu \mathrm{g} / \mathrm{kg}$, five treatments at $15 \mu \mathrm{g} / \mathrm{kg}$, and five at $10 \mu \mathrm{g} / \mathrm{kg}$ ). Then, each mouse that survived up to 20 weeks was dosed as follows: $19.2 \mu \mathrm{g} / \mathrm{kg}$ (group 1), $19.6 \mu \mathrm{g} / \mathrm{kg}$ (group 2), $8.2 \mu \mathrm{g} / \mathrm{kg}$ (group 3), $7.7 \mu \mathrm{g} / \mathrm{kg}$ (group 4), and $4.3 \mu \mathrm{g}$ AZA1/ $/ \mathrm{kg}$ (group 5). Sixty-six mice were sacrificed at 8 months and did not show any tumor. However, multiple lymphatic nodules were observed in the lungs of 10/27 mice at 8 months from groups 1 and 3 . In the residual 20 mice (ten mice of group 2, six of group 3, and four of group 4), five tumors were noted within 1 year. They included two malignant lymphomas and three lung tumors (one adenocarcinoma and two epithelial-type tumors), but one lung tumor was noted also in controls (EFSA 2008; Ito 2008; Ito et al. 2004). Since the ICR mice used in the study show a relatively high ratio of spontaneous tumors at 2 years, it has been suggested that the nine recorded tumors at 1 year might be spontaneous.

Nevertheless, it has to be considered the possibility that AZA1 could be tumorigenic by itself or a tumor promoter (Ito 2008; Ito et al. 2004).

\section{Mutagenicity and Genotoxicity}

No mutagenicity or genotoxicity data are available for AZAs.

\section{Tumor Promotion}

Even though tumors were noted in 9/126 (7\%) in a 1-year toxicity study in mice, treated with repeated oral doses of AZA1 ( 20 or $50 \mu \mathrm{g} / \mathrm{kg}$ ), further studies should be carried out to confirm the toxin carcinogenicity or its tumor promotion activity (Ito 2008; Ito et al. 2004).

\section{Treatment}

Similarly to DSP, no specific antidotes are currently available for AZP, which treatment is only symptomatic and supportive.

\section{Conclusion and Future Directions}


Since the initial isolation of AZAs from shellfish implicated in poisoning events in the mid-1990s, much progress has been made over the last decade, both in terms of chemical and toxicological understanding. Semi-preparative purification allowed for structural clarification for 16 of more than 30 known analogues. Also, metabolism pathways have been clarified in shellfish, in particular mussels. As a consequence, several currently non-regulated analogues have been pointed out to be of importance: AZA6, AZA17, and AZA19, and official control procedures should be revised to take account of these analogues as their occurrence is going to be an important knowledge in future risk assessment exercises.

The discovery of a producing organism, Azadinium spinosum, reported in 2009, has clarified why the biological origin remained cryptic for about 12 years: the organism is very small and easily destroyed in standard procedures for phytoplankton analysis. Since then, 11 other species have been identified in this new and one related genus ( Amphidoma), resulting in four species known to produce AZAs ( Azadinium spinosum, Azadinium poporum, Azadinium dexteroporum, Amphidoma languida). The recently established worldwide distribution of these species and the reports of toxins accumulating in shellfish from all regions of the globe raise the hope that knowledge will rapidly increase for more complete epidemiological studies.

Complete clarification of the mode of action of AZAs is still lacking and thus impedes development of a medical treatment, other than the current treatment of the gastrointestinal symptoms. Further isolation of toxins and in-depth toxicological studies are also required to assess the potential effects of low-level repeated exposure or co-exposure with other toxins or contaminants.

\section{Cross-References}

Okadaic Acid and Other Diarrheic Toxins: Toxicological Profile

\section{References}

Aasen JA, Espenes A, Hess P, Aune T. Sub-lethal dosing of azaspiracid-1 in female NMRI mice. Toxicon. 2010;56:1419-25.

CrossRef PubMed

Aasen JAB, Espenes A, Miles CO, Samdal IA, Hess P, Aune T. Combined oral toxicity of azaspiracid-1 and yessotoxin in female NMRI mice. Toxicon. 2011;57:909-17.

CrossRef PubMed

Akselman R, Negri RM. Blooms of Azadinium cf. spinosum Elbrächter et Tillmann (Dinophyceae) in northern shelf waters of Argentina, Southwestern Atlantic. Harmful Algae. 2012;19:30-8.

CrossRef

Alfonso A, Vieytes MR, Ofuji K, Satake M, Nicolaou KC, Frederick MO, Botana LM. Azaspiracids modulate intracellular $\mathrm{pH}$ levels in human lymphocytes. Biochem Biophys Res Commun.

2006;346:1091-9. 
Alfonso C, Rehmann N, Hess P, Alfonso A, Wandscheer CB, Abuín M, Vale C, Otero P, Vieytes MR, Botana LM. Evaluation of various $\mathrm{pH}$ and temperature conditions on the stability of azaspiracids and their importance in preparative isolation and toxicological studies. Anal Chem. 2008;80:9672-80. CrossRef PubMed

Álvarez G, Uribe E, Ávalos P, Mariño C, Blanco J. First identification of azaspiracid and spirolides in Mesodesma donacium and Mulinia edulis from Northern Chile. Toxicon. 2010;55:638-41.

CrossRef PubMed

Amzil Z, Sibat M, Royer F, Savar V. First report on azaspiracid and yessotoxin groups detection in French shellfish. Toxicon. 2008;52:39-48.

CrossRef PubMed

Aune A, Espenes A, Aasen JAB, Quilliam MA, Hess P, Larsen S. Study of possible combined toxic effects of azaspiracid-1 and okadaic acid in mice via the oral route. Toxicon. 2012;60:895-906.

CrossRef PubMed

Cao Z, LePage KT, Frederick MO, Nicolaou KC, Murray TF. Involvement of caspase activation in azaspiracid-induced neurotoxicity in neocortical neurons. Toxicol Sci. 2010;114:323-34.

PubMedCentral CrossRef PubMed

Cembella AD. Ecophysiology and metabolism of paralytic shellfish toxins in marine microalgae. In: Anderson DM, Cembella AD, Hallegraeff GM, editors. Physiological ecology of harmful algal blooms. Berlin/Heidelberg/New York: Springer; 1998. p. 381-403.

Chevallier OP, Graham SF, Alonso E, Duffy C, Silke J, Campbell K, Botana LM, Elliott CT. New insights into the causes of human illness due to consumption of azaspiracid contaminated shellfish. Sci Rep. 2015;5:9818.

PubMedCentral CrossRef PubMed

Cohen P. The structure and regulation of protein phosphatases. Annu Rev Biochem. 1989;58:453508.

CrossRef PubMed 
EFSA. Marine biotoxins in shellfish - azaspiracid group, scientific opinion of the panel on contaminants in the food chain, adopted on 9 June 2008. EFSA J. 2008;723:1-52.

Elgarch A, Vale P, Rifai S, Fassouane A. Detection of diarrheic shellfish poisoning and azaspiracid toxins in Moroccan mussels: comparison of the LC-MS method with the commercial immunoassay kit. Mar Drugs. 2008;6:587-94.

PubMedCentral CrossRef PubMed

Ferreiro SF, Vilariño N, Carrera C, Louzao MC, Santamarina G, Cantalapiedra AG, Rodríguez LP, Cifuentes JM, Vieira AC, Nicolaou KC, Frederick MO, Botana LM. In vivo arrhythmogenicity of the marine biotoxin azaspiracid-2 in rats. Arch Toxicol. 2014a;88:425-34.

PubMedCentral CrossRef PubMed

Ferreiro SF, Vilariño N, Louzao MC, Nicolaou KC, Frederick MO, Botana LM. In vitro chronic effects on hERG channel caused by the marine biotoxin azaspiracid-2. Toxicon. 2014b;91:69-75. CrossRef PubMed

Flanagan AF, Kane M, Donlon J, Palmer R. Azaspiracid, detection of a newly discovered phycotoxin in vitro. J Shellfish Res. 1999;18:716.

Flanagan AF, Callanan KR, Donlon J, Palmer R, Forde A, Kane M. A cytotoxicity assay for the detection and differentiation of two families of shellfish toxins. Toxicon. 2001;39:1021-7.

CrossRef PubMed

Furey A, Moroney C, Braña Magdalena A, Saez MJF, Lehane M, James KJ. Geographical, temporal, and species variation of the polyether toxins, azaspiracids, in shellfish. Environ Sci Technol.

2003;37:3078-84.

CrossRef PubMed

Furey A, O'Doherty S, O'Callaghan K, Lehane M, James KJ. Azaspiracid poisoning (AZP) toxins in shellfish: toxicological and health considerations. Toxicon. 2010;56:173-90.

CrossRef PubMed

Fux E, Biré R, Hess P. Comparative accumulation and composition of lipophilic marine biotoxins in passive samplers and in mussels ( M. edulis) on the West Coast of Ireland. Harmful Algae.

2009;8:523-37.

CrossRef 
Gu HF, Luo ZH, Krock B, Witt M, Tillmann U. Morphology, phylogeny and azaspiracid profile of Azadinium poporum (Dinophyceae) from the China Sea. Harmful Algae. 2013;21-22:64-75.

CrossRef

Hess P. Use of LC-MS testing to identify lipophilic toxins, to establish local trends and interspecies differences and to test the comparability of LC-MS testing with the mouse bioassay: an example from the Irish biotoxin monitoring programme 2001. In: Villalba A, Reguera B, Romalde JL, Beiras R, editors. Fourth International Conference on Molluscan Shellfish Safety, 4-8 June, 2002. Santiago de Compostela: IOC of UNESCO; 2002. p. 57-66.

Hess P, McCarron P, Rehmann N, Kilcoyne J, McMahon T, Ryan G, Ryan PM, Twiner MJ, Doucette GJ, Satake M, Ito E, Yasumoto T. Isolation and purification of azaspiracids from naturally contaminated materials, and evaluation of their toxicological effects. Final project report ASTOX (ST/02/02). Marine Institute - Marine Environment \& Health Series, Rinville, Co. Galway 2007;129.

Hess P, McCarron P, Krock B, Kilcoyne J, Miles CO. Azaspiracids: chemistry, biosynthesis, metabolism, and detection, seafood and freshwater toxins. Boca Raton: CRC Press; 2014. p. 799-822. CrossRef

Ito E. Toxicology of azaspiracid-1: acute and chronic poisoning, tumorigenicity, and chemical structure relationship to toxicity in a mouse model. In: Botana LM, editor. Seafood and Freshwater Toxins: pharmacology, physiology and detection. Boca Raton: CRC Press; 2008.

Ito E, Satake M, Ofuji K, Kurita N, McMahon T, James K, Yasumoto T. Multiple organ damage caused by a new toxin azaspiracid, isolated from mussels produced in Ireland. Toxicon. 2000;38:91730.

CrossRef PubMed

Ito E, Satake M, Ofuji K, Higashi M, Harigaya K, McMahon T, Yasumoto T. Chronic effects in mice caused by oral administration of sublethal doses of azaspiracid, a new marine toxin isolated from mussels. Toxicon. 2002;40:193-203.

CrossRef PubMed

Ito E, Satake M, Ofuji K, McKahon T, Yasumoto T. Pathological study of azaspiracid poisoning in mice. In: Henshilwood K, Deegan B, Mcmahon T, Cusack C, Keaveney S, Silke J, O' Cinneide M, Lyons D, Hess P, editors. Proceedings of the 5th International Conference Molluscan Shellfish Safety, 14-18 June 2004, Galway; 2004. 
Ito E, Frederick MO, Koftis TV, Tang W, Petrovic G, Ling T, Nicolaou KC. Structure toxicity relationships of synthetic azaspiracid-1 and analogs in mice. Harmful Algae. 2006;5:586-91. CrossRef

James KJ, Furey A, Lehane M, Moroney C, Satake M, Yasumoto T. LC-MS methods for the investigation of a new shellfish toxic syndrome - azaspiracid poisoning (AZP). In Mycotoxins and Phycotoxins in Perspective at the Turn of the Century. deKeo WJ. Samson RA, van Egmond HP, Gilbert J, Sabino M, editors. Wageningen, The Netherlands, 2001;401-408.

James KJ, Furey A, Lehane M, Ramstad H, Aune T, Hovgaard P, Morris S, Higman W, Satake M, Yasumoto T. First evidence of an extensive northern European distribution of azaspiracid poisoning (AZP) toxins in shellfish. Toxicon. 2002;40:909-15.

CrossRef PubMed

James KJ, Moroney C, Roden C, Satake M, Yasumoto T, Lehane M, Furey A. Ubiquitous 'benign' alga emerges as the cause of shellfish contamination responsible for the human toxic syndrome, azaspiracid poisoning. Toxicon. 2003a;41:145-51.

CrossRef PubMed

James KJ, Sierra MD, Lehane M, Braña Magdalena A, Furey A. Detection of five new hydroxyl analogues of azaspiracids in shellfish using multiple tandem mass spectrometry. Toxicon.

2003b;41:277-83.

CrossRef PubMed

James KJ, Saez MJF, Furey A, Lehane M. Azaspiracid poisoning, the food-borne illness associated with shellfish consumption. Food Addit Contam. 2004;21:879-92.

CrossRef PubMed

James KJ, Furey A, Satake M, Yasumoto T. Azaspiracid poisoning (AZP): a new shellfish toxic syndrome in Europe. In: Hallegraeff GM, Blackburn SI, Bolch CJ, Lewis RJ, editors. Harmful algal blooms 2000. Intergovernmental Oceanographic Commission of UNESCO, Paris, France, 2001. pp. 250-253.

Jauffrais T, Herrenknecht C, Séchet V, Sibat M, Tillmann U, Krock B, Kilcoyne J, Miles C, McCarron P, Amzil Z, Hess P. Quantitative analysis of azaspiracids in Azadinium spinosum cultures. Anal Bioanal Chem. 2012a;403:833-46.

CrossRef PubMed 
Jauffrais T, Kilcoyne J, Séchet V, Herrenknecht C, Truquet P, Hervé F, Bérard JB, Nulty C, Taylor S, Tillmann U, Miles CO, Hess P. Production and isolation of azaspiracid-1 and -2 from Azadinium spinosum culture in pilot scale photobioreactors. Mar Drugs. 2012b;10:1360-82.

PubMedCentral CrossRef PubMed

Jauffrais T, Marcaillou C, Herrenknecht C, Truquet P, Séchet V, Nicolau E, Tillmann U, Hess P. Azaspiracid accumulation, detoxification and biotransformation in blue mussels ( Mytilus edulis) experimentally fed Azadinium spinosum. Toxicon. 2012c;60:582-95.

CrossRef PubMed

Kilcoyne J, Keogh A, Clancy G, LeBlanc P, Burton IW, Quilliam MA, Hess P, Miles CO. Improved isolation procedure for azaspiracids from shellfish, structural elucidation of azaspiracid-6, and stability studies. J Agric Food Chem. 2012;60:2447-55.

CrossRef PubMed

Kilcoyne J, McCarron P, Twiner MJ, Nulty C, Crain S, Quilliam MA, Rise F, Wilkins AL, Miles CO. Epimers of azaspiracids: isolation, structural elucidation, relative LC-MS response, and in vitro toxicity of 37- epi-azaspiracid-1. Chem Res Toxicol. 2014a;27:587-600.

CrossRef PubMed

Kilcoyne J, Nulty C, Jauffrais T, McCarron P, Herve F, Foley B, Rise F, Crain S, Wilkins AL, Twiner MJ, Hess P, Miles CO. Isolation, structure elucidation, relative LC-MS response, and in vitro toxicity of azaspiracids from the dinoflagellate Azadinium spinosum. J Nat Prod. 2014b;77:2465-74.

CrossRef PubMed

Kilcoyne J, Jauffrais T, Twiner MJ, Doucette G, Aasen Bunæs J A, Sosa S, Krock B, Séchet V, Nulty C, Salas R, Clarke D, Geraghty J, Duffy C, Foley B, John U, Quilliam MA, McCarron P, Miles CO, Silke J, Cembella A, Tillmann U, Hess P. Azaspiracids - toxicological evaluation, test methods and identifcation of the source organisms (ASTOX II); Marine Institute - Marine Research SubProgramme (NDP 2007-2013) series (http://oar.marine.ie/handle/10793/970), 2014c.

Kilcoyne J, Twiner MJ, McCarron P, Crain S, Giddings SD, Foley B, Rise F, Hess P, Wilkins AL, Miles CO. Structure elucidation, relative LC-MS response and in vitro toxicity of azaspiracids 7-10 isolated from mussels ( Mytilus edulis). J Agric Food Chem. 2015;63:5083-91.

CrossRef PubMed 
Kittler K, Preiss-Weigert A, These A. Identification strategy using combined mass spectrometric techniques for elucidation of phase I and phase II in vitro metabolites of lipophilic marine biotoxins. Anal Chem. 2010;82:9329-35.

CrossRef PubMed

Klontz KC, Abraham A, Plakas SM, Dickey RW. Mussel-associated azaspiracid intoxication in the United States. Ann Intern Med. 2009;150:361.

CrossRef PubMed

Krock B, Tillmann U, John U, Cembella A. LC-MS-MS aboard ship: tandem mass spectrometry in the search for phycotoxins and novel toxigenic plankton from the North Sea. Anal Bioanal Chem. 2008;392:797-803.

CrossRef PubMed

Krock B, Tillmann U, John U, Cembella AD. Characterization of azaspiracids in plankton sizefractions and isolation of an azaspiracid-producing dinoflagellate from the North Sea. Harmful Algae. 2009;8:254-63.

CrossRef

Krock B, Tillmann U, Voß D, Koch BP, Salas R, Witt M, Potvin É, Jeong HJ. New azaspiracids in Amphidomataceae (Dinophyceae). Toxicon. 2012;60:830-9.

CrossRef PubMed

Kulagina KV, Twiner MJ, Hess P, McMahon T, Satake M, Yasumoto T, Ramsdell JS, Doucette GJ, Ma W, O'Shaughnessy TJ. Azaspiracid-1 inhibits bioelectrical activity of spinal cord neuronal networks. Toxicon. 2006;47:766-73.

CrossRef PubMed

Lehane M, Braña Magdalena A, Moroney C, Furey A, James KJ. Liquid chromatography with electrospray ion trap mass spectrometry for the determination of five azaspiracids in shellfish. $\mathrm{J}$ Chromatogr A. 2002;950:139-47.

CrossRef PubMed

López-Rivera A, O'Callaghan K, Moriarty M, O’Driscoll D, Hamilton B, Lehane M, James KJ, Furey A. First evidence of azaspiracids (AZAs): a family of lipophilic polyether marine toxins in scallops ( Argopecten purpuratus) and mussels ( Mytilus chilensis) collected in two regions of Chile. Toxicon. 2010;55:692-701.

CrossRef PubMed 
Magdalena AB, Lehane M, Krys S, Fernandez ML, Furey A, James KJ. The first identification of azaspiracids in shellfish from France and Spain. Toxicon. 2003a;42:105-8.

CrossRef PubMed

Magdalena AB, Lehane M, Moroney C, Furey A, James KJ. Food safety implications of the distribution of azaspiracids in the tissue compartments of scallops ( Pecten maximus). Food Addit Contam. 2003b;20:154-60.

CrossRef PubMed

McCarron P, Emteborg H, Hess P. Freeze-drying for the stabilisation of shellfish toxins in mussel tissue ( Mytilus edulis) reference materials. Anal Bioanal Chem. 2007;387:2475-86.

CrossRef PubMed

McCarron P, Kilcoyne J, Miles CO, Hess P. Formation of azaspiracids-3,-4,-6, and-9 via decarboxylation of carboxyazaspiracid metabolites from shellfish. J Agric Food Chem. 2009;57:1609 .

CrossRef PubMed

McCarron P, Giddings S, Quilliam M. A mussel tissue certified reference material for multiple phycotoxins. Part 2: liquid chromatography-mass spectrometry, sample extraction and quantitation procedures. Anal Bioanal Chem. 2011;400:835-46.

CrossRef PubMed

McMahon T, Silke J. West coast of Ireland; winter toxicity of unknown aetiology in mussels. Harmful Algae News. 1996;14:2.

Nicolaou KC, Koftis TV, Vyskocil S, Petrovic G, Tang W, Frederick MO, Chen DYK, Yiwei L, Ling T, Yamada TMA. Total synthesis and structural elucidation of azaspiracid-1. Final assignment and total synthesis of the correct structure of azaspiracid-1. J Am Chem Soc. 2004;128:2859-72.

CrossRef

Nzoughet KJ, Hamilton JTG, Floyd SD, Douglas A, Nelson J, Devine L, Elliott CT. Azaspiracid: first evidence of protein binding in shellfish. Toxicon. 2008;51:1255-63.

CrossRef PubMed 
O’Driscoll D, Škrabáková Z, O’Halloran J, van Pelt FNAM, James KJ. Mussels increase xenobiotic (azaspiracid) toxicity using a unique bioconversion mechanism. Environ Sci Technol. 2011;45:31028.

CrossRef PubMed

Ofuji K, Satake M, McMahon T, Silke J, James KJ, Naoki H, Oshima Y, Yasumoto T. Two analogs of azaspiracid isolated from mussels, Mytilus edulis, involved in human intoxication in Ireland. Nat Toxins. 1999;7:99-102.

CrossRef PubMed

Ofuji K, Satake M, McMahon T, James KJ, Naoki H, Oshima Y, Yasumoto T. Structures of azaspiracid analogs, azaspiracid-4 and azaspiracid-5, causative toxins of azaspiracid poisoning in Europe. Biosci Biotechnol Biochem. 2001;65:740-2.

CrossRef PubMed

Percopo I, Siano R, Rossi R, Soprano V, Sarno D, Zingone A. A new potentially toxic Azadinium species (Dinophyceae) from the Mediterranean Sea, A. dexteroporum sp. nov. J Phycol. 2013;49:95066.

Perez R, Rehmann N, Crain S, LeBlanc P, Craft C, MacKinnon S, Reeves K, Burton I, Walter J, Hess $\mathrm{P}$, Quilliam M, Melanson J. The preparation of certified calibration solutions for azaspiracid-1, -2, and -3 , potent marine biotoxins found in shellfish. Anal Bioanal Chem. 2010;398:2243-52.

CrossRef PubMed

Potvin É, Jeong HJ, Kang NS, Tillmann U, Krock B. First report of the photosynthetic dinoflagellate genus Azadinium in the Pacific Ocean: morphology and molecular characterization of Azadinium cf. poporum. J Eukaryotic Microbiol. 2012;59:145-56.

CrossRef

RASFF. The Rapid Alert System for Food and Feed (RASFF) Annual Report 2008, http://ec.europa. eu/food/food/rapidalert/report2008_en.pdf. 2008.

Rehmann N, Hess P, Quilliam MA. Discovery of new analogs of the marine biotoxin azaspiracid in blue mussels ( Mytilus edulis) by ultra-performance liquid chromatography/tandem mass spectrometry. Rapid Commun Mass Spectrom. 2008;22:549-58.

CrossRef PubMed 
Roman Y, Alfonso A, Louzao MC, de la Rosa LA, Leira F, Vieites JM, Vieytes MR, Ofuji K, Satake M, Yasumoto T, Botana LM. Azaspiracid-1, a potent, nonapoptotic new phycotoxin with several cell targets. Cell Signalling. 2002;14:703-16.

CrossRef PubMed

Rundberget T, Sandvik M, Larsen K, Pizarro GM, Reguera B, Castberg T, Gustad E, Loader JI, Rise F, Wilkins AL, Miles CO. Extraction of microalgal toxins by large-scale pumping of seawater in Spain and Norway, and isolation of okadaic acid and dinophysistoxin-2. Toxicon. 2007;50:960-70. CrossRef PubMed

Ryan G, Cunningham K, Ryan MP. Pharmacology and epidemiological impact of azaspiracids. In: Botana LM, editor. Seafood and freshwater toxins: pharmacology, physiology, and detection. 2nd ed. Boca Raton: CRC Press (Taylor and Francis Group); 2008. p. 755-61.

CrossRef

Salas R, Tillmann U, John U, Kilcoyne J, Burson A, Cantwell C, Hess P, Jauffrais T, Silke J. The role of Azadinium spinosum (Dinophyceae) in the production of azaspiracid shellfish poisoning in mussels. Harmful Algae. 2011;10:774-83.

CrossRef

Sanguinetti MC, Tristani-Firouzi M. hERG potassium channels and cardiac arrhythmia. Nature. 2006;440:463-9.

CrossRef PubMed

Satake M, Ofuji K, James KJ, Furey A, Yasumoto T. New toxic event caused by Irish mussels. In: Reguera B, Blanco J, Fernandez ML, Wyatt T, editors. Harmful algae, proceedings of the VIII international conference on harmful algae, (June 1999, Vigo, Spain). Santiago de Compostela: Xunta de Galicia and Intergovernmental Oceanographic Commission of UNESCO; 1998a. p. 468-9.

Satake M, Ofuji K, Naoki H, James KJ, Furey A, McMahon T, Silke J, Yasumoto T. Azaspiracid, a new marine toxin having unique spiro ring assemblies, isolated from Irish mussels, Mytilus edulis. J Am Chem Soc. 1998b;120:9967-8.

CrossRef

Taleb H, Vale P, Amanhir R, Benhadouch A, Sagou R, Chafik A. First detection of azaspiracids in mussels in north west Africa. J Shellfish Res. 2006;25:1067-70.

CrossRef 
Tillmann U, Elbrächter M, Krock B, John U, Cembella AD. Azadinium spinosum gen. et $\mathrm{sp}$. nov (Dinophyceae) identified as a primary producer of azaspiracid toxins. Eur J Phycol. 2009;44:63-79. CrossRef

Tillmann U, Elbrächter M, John U, Krock B, Cembella AD. Azadinium obesum (Dinophyceae), a new nontoxic species in the genus that can produce azaspiracid toxins. Phycologia. 2010;49:169-82.

CrossRef

Tillmann U, Elbrächter M, John U, Krock B. A new non-toxic species in the dinoflagellate genus Azadinium: A. poporum sp. nov. Eur J Phycol. 2011;46:74-87.

CrossRef

Tillmann U, Salas R, Gottschling M, Krock B, O’Driscoll D, Elbrächter M. Amphidoma languida sp. nov. (Dinophyceae) reveals a close relationship between Amphidoma and Azadinium. Protist. 2012;163:701-19.

CrossRef PubMed

Tillmann U, Salas R, Jauffrais T, Hess P, Silke J. AZA: the producing organisms - biology and trophic transfer. In: Botana LM, editor. Seafood and freshwater toxins. Boca Raton: CRC Press; 2014. p. 773-98.

CrossRef

Torgersen T, Aasen J, Aune T. Diarrhetic shellfish poisoning by okadaic acid esters from brown crabs ( Cancer pagurus) in Norway. Toxicon. 2005;46:572-8.

CrossRef PubMed

Torgersen T, Bremnes NB, Rundberget T, Aune T. Structural confirmation and occurrence of azaspiracids in Scandinavian brown crabs ( Cancer pagurus). Toxicon. 2008;51:93-101.

CrossRef PubMed

Tubaro A, Kilcoyne J, Pelin M, D'Orlando E, Beltramo D, Nulty C, Hess P, Sosa S. Acute oral toxicity of three azaspiracid analogues in mice. Toxicon. 2014;91:183.

CrossRef

Twiner MJ, Hess P, Bottein Dechraoui M-Y, McMahon T, Samons MS, Satake M, Yasumoto T, Ramsdell JS, Doucette GJ. Cytotoxic and cytoskeletal effects of azaspiracid-1 on mammalian cell lines. Toxicon. 2005;45:891-900.

CrossRef PubMed 
Twiner MJ, Rehmann N, Hess P, Doucette GJ. Azaspiracid shellfish poisoning: a review on the chemistry, ecology, and toxicology with an emphasis on human health impacts. Mar Drugs. 2008;6:39-72.

PubMedCentral CrossRef PubMed

Twiner MJ, Doucette GJ, Rasky A, Huang X-P, Roth BL, Sanguinetti MC. The marine algal toxin azaspiracid is an open state blocker of hERG potassium channels. Chem Res Toxicol. 2012a;25:197584.

PubMedCentral CrossRef PubMed

Twiner MJ, El-Ladki R, Kilcoyne J, Doucette GJ. Comparative effects of the marine algal toxins azaspiracid-1, -2, and -3 on Jurkat T lymphocyte cells. Chem Res Toxicol. 2012b;25:747-54.

CrossRef PubMed

Twiner MJ, Hess P, Doucette GJ. Azaspiracids: toxicology, pharmacology, and risk assessment, seafood and freshwater toxins. Boca Raton: CRC Press; 2014. p. 823-56.

CrossRef

Ueoka R, Ito A, Izumikawa M, Maeda S, Takagi M, Shin-ya K, Yoshida M, van Soest RWM, Matsunaga S. Isolation of azaspiracid-2 from a marine sponge Echinoclathria sp. as a potent cytotoxin. Toxicon. 2009;53:680-4.

CrossRef PubMed

Vale C, Gomez-Limia B, Nicolaou KC, Frederick MO, Vieytes MR, Botana LM. The c-Jun-Nterminal kinase is involved in the neurotoxic effect of azaspiracid-1. Cell Physiol Biochem. 2007;20:957-66.

CrossRef PubMed

Vale C, Nicolaou KC, Frederick MO, Vieytes MR, Botana LM. Cell volume decrease as a link between azaspiracid-induced cytotoxicity and c-Jun-N-terminal kinase activation in cultured neurons. Toxicol Sci. 2010;113:158-68.

PubMedCentral CrossRef PubMed 